\title{
Morphometric Analysis of Stylomastoid Foramen Location and its Clinical Importance
}

\author{
Hemanth Ragav N V and Yuvaraj Babu $\mathrm{K}^{2 *}$ \\ ${ }^{1}$ Saveetha Dental College and Hospitals, Saveetha Institute of Medical and \\ Technical Sciences, Saveetha University, Chennai- 600077, India \\ ${ }^{2}$ Assistant Professor, Department of Anatomy, Saveetha Dental College and Hospitals, Saveetha \\ Institute of Medical and Technical Science, Saveetha University, Chennai- 600077, India
}

\section{ABSTRACT}

The stylomastoid foramen is located between the styloid process and mastoid process of the temporal bone. Facial nerve and Stylomastoid branch of posterior auricular artery passes through this stylomastoid foramen. The facial nerve can be blocked at this stylomastoid foramen but it has high risk of nerve damage. For Nadbath facial nerve block, stylomastoid foramen is the most important site. Facial canal ends at this foramen and it is the important motor portion of this stylomastoid foramen. A total of 50 dry skulls from the Anatomy Department of Saveetha Dental College were studied to locate the position of the centre of the stylomastoid foramen with respect to the tip of mastoid process and the articular tubercle of the zygomatic arch by a digital vernier caliper. All measurements were tabulated and statistically analysed. In our study, we found the mean distance of stylomastoid foramen from mastoid processes $16.31 \pm 2.37 \mathrm{~mm}$ and $16.01 \pm 2.08$ $\mathrm{mm}$ on right and left. Their range is $10.48-23.34 \mathrm{~mm}$ and $11.5-21.7 \mathrm{~mm}$. The mean distance of stylomastoid foramen from articular tubercle is $29.48 \pm 1.91 \mathrm{~mm}$ and $29.90 \pm 1.62 \mathrm{~mm}$ on right and left. Their range is $26.77-34.73 \mathrm{~mm}$ and 26.72-34.17 $\mathrm{mm}$. This study helps to determine the precise location of the stylomastoid foramen in relation to various anatomical structures which will be very helpful for the surgeons to plan surgeries in this region.

KEY WORDS: STYLOMASTOID FORAMEN, FACIAL NERVE BLOCK, MASTOID PROCESS, ARTICULAR TUBERCLE.

\section{INTRODUCTION}

The stylomastoid foramen is located between the styloid process and mastoid process of the temporal bone. Facial nerve and Stylomastoid branch of posterior auricular artery passes through this stylomastoid foramen (Varshney and Sharma, 2015). The facial nerve can be blocked at this stylomastoid foramen but it has high risk of nerve damage. For Nadbath facial nerve block,

\section{ARTICLE INFORMATION}

*Corresponding Author: yuvarajbabu@saveethal.com Received 8th Aug 2020 Accepted after revision 29th Sep 2020 Print ISSN: 0974-6455 Online ISSN: 2321-4007 CODEN: BBRCBA

Thomson Reuters ISI Web of Science Clarivate Analytics USA and Crossref Indexed Journal

\section{Clarivate
Analytics}

NAAS Journal Score 2020 (4.31) SJIF: 2020 (7.728)

A Society of Science and Nature Publication,

Bhopal India 2020. All rights reserved.

Online Contents Available at: http//www.bbrc.in/

Doi: http://dx.doi.org/10.21786/bbrc/13.8/120 stylomastoid foramen is the most important site (Nadbath and Rehman, 1963). Facial canal ends at this foramen and it is the important motor portion of this stylomastoid foramen. The facial nerve travels along the bony canal and proceeds the nerve towards the stapedius along the chorda tympani (Karaca et al., 2019). The root of the styloid process is anterior to stylomastoid foramen and lateral to jugular foramen. The structures present around the stylomastoid foramen are the styloid process, mastoid process, jugular surface and stylopharyngeus.

When describing the stylomastoid foramen various researches have studied the importance of various anatomical structures that are passing through the stylomastoid foramen. Stylomastoid Foramen is the most frequently employed method of anesthesia in cataract surgery. Knowing the exact location of the foramen is of great importance to surgeons and anaesthetists in locating the trunk of the facial nerve in various procedures 
(Wakasugi, 1972). There are four types of facial block: van Lint's block, Atkinson block, 0' Brien block and Nadbath block(Hessemer, 1994). Van Lint's block: The peripheral branches of the facial nerve are blocked within van Lint 's block. $2.5 \mathrm{ml}$ of anesthetic solution is administered just above the eyebrow and below the lower orbital margin, $2 \mathrm{~cm}$ below the lateral orbital margin at the edge of the outer eye canthus(Schimek and Fahle, 1995). 0' Brien's block: Otherwise known as facial nerve trunk block. The block is done at the level of the neck of the mandible near the condylar process(Warner, Martino and Davidson, 1995). Atkinson's block: The superior branch of the facial nerve is blocked by inserting the anesthetic solution at the inferior zygomatic bone margin. Nadbath block: Furthermore, called as modified O'Brien's method. Here the facial nerve is blocked at the stylomastoid foramen.

With a rich case bank established over 3 decades we have been able to publish extensively in our domain

Figure 1: Measurement of Distance between Stylomastoid foramen to mastoid process (A) and articular tubercle (B)

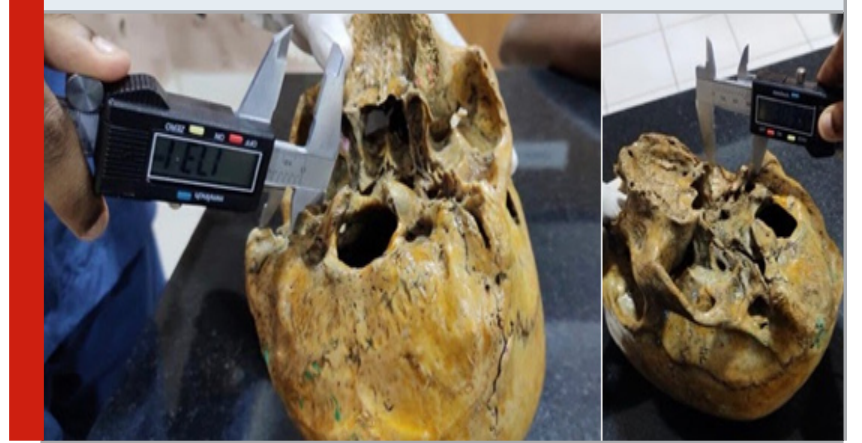

(Abdul Wahab et al., 2017; Eapen, Baig and Avinash, 2017; Patil et al., 2017; Jain and Nazar, 2018; J et al., 2018; Marimuthu et al., 2018; Wahab et al., 2018; Abhinav et al., 2019; Ramadorai, Ravi and Narayanan, 2019; Senthil Kumar et al., 2019; Sweta, Abhinav and Ramesh, 2019). Based on this inspiration we aim to locate the styloid foramen with two measurements, from the tip of the mastoid process to stylomastoid foramen and the other measurement is from the articular tubercle to the stylomastoid foramen. Most of the previous studies located stylomastoid foramen with respect to the tip of mastoid process and jugular foramen. But here we also measure the distance with the articular tubercle which was not done by any other author. With this we can find the exact location of stylomastoid foramen.

\section{MATERIAL AND METHODS}

A total of 50 dry unsexed skulls from the Anatomy Department of Saveetha Dental College were examined to locate the position of the centre of the stylomastoid foramen with respect to the tip of mastoid process and the articular tubercle of the zygomatic arch by a digital vernier caliper (Figure $1 \mathrm{~A}, \mathrm{~B}$ ). All measurements were tabulated and statistically analysed.

\section{RESULTS AND DISCUSSION}

In our study, we found the mean length of stylomastoid foramen to mastoid process $16.31 \pm 2.37 \mathrm{~mm}$ and $16.01 \pm 2.08 \mathrm{~mm}$ on right and left. Their range is 10.48 $23.34 \mathrm{~mm}$ and $11.5-21.7 \mathrm{~mm}$. The mean length of stylomastoid foramen to articular tubercle is $29.48 \pm 1.91$ $\mathrm{mm}$ and $29.90 \pm 1.62 \mathrm{~mm}$ on right and left. Their range is $26.77-34.73 \mathrm{~mm}$ and $26.72-34.17 \mathrm{~mm}$

\begin{tabular}{l} 
Table 1. Range and mean distance of Stylomastoid foramen from mastoid process and \\
articular tubercle right and left side. \\
\hline
\end{tabular}

Previous author studied about the morphometric analysis of stylomastoid foramen and its clinical application in facial nerve block with a total of 100 dry skulls and found the mean distance of centre of foramen from the tip of mastoid process as $16.01 \pm 2.08 \mathrm{~mm}$ on right and $16.31 \pm 2.37 \mathrm{~mm}$ on left side. He also showed that $83.5 \%$ of skulls had stylomastoid foramen located anterior to the line passing through the anterior border of the mastoid process (Varshney and Sharma, 2015). Another author concluded that the position of stylomastoid foramen for the left side is 50\% along the XY axis. Also said that the left side distance was higher than the right side distance and this can also be referred for Nadbath facial block (Kumagami, Nishida and Dohi, 1976).
Another study concluded that the trunk of the facial nerve was in proximity to the stylomastoid artery, which originated from the posterior auricular artery in $70 \%$ of the specimens, from the occipital artery it is $20 \%$ and directly from the external carotid artery it is $10 \%$. The stylomastoid artery passed medially to the trunk of the facial nerve in 63 of the specimens and laterally in 37\% (Bourdon et al., 2000).

Knowledge of the trunk of the facial nerve is essential for preserving the nerve during surgical procedures of the mastoid process, parotid gland, the cranial base and the facial nerve (Baker and Conley, 1979). Most commonly, the facial nerve is in relation to the stylomastoid 
artery that arises from the posterior auricular artery. The stylomastoid artery also originates from occipital or peripheral carotid arteries. In 19 cases of 30 the stylomastoid artery passes medially to the nerve, and 11 cases laterally [Moreau et al, 2001]. Another study concluded during the examination of cranial bones, we observed an abnormality in one of the right temporal bones. In this variation, the stylomastoid foramen was not completely formed on the temporal bone, and instead of the foramen, the sulcus was located on the bone [Celik et al, 1997]

No author took the distance of stylomastoid foramen with respect to articular tubercles. There was no significant difference in the location of stylomastoid foramen between its sides from the anatomical landmarks.

\section{CONCLUSION}

This study helps to determine the precise location of the stylomastoid foramen in relation to various anatomical structures which will be very helpful for the surgeons to plan surgery in this region.

\section{ACKNOWLEDGEMENTS}

We acknowledge Department of Anatomy for allowing us to use bones from their collection for this study

Conflict of Interest: The author declares that there is no conflict of interest in the present study.

\section{REFERENCES}

Abdul Wahab, P. U. et al. (2017) 'Risk Factors for Postoperative Infection Following Single Piece Osteotomy', Journal of maxillofacial and oral surgery, 16(3), pp. 328-332. doi: 10.1007/s12663-016-0983-6.

Abhinav, R. P. et al. (2019) 'The Patterns and Etiology of Maxillofacial Trauma in South India', Annals of maxillofacial surgery, 9(1), pp. 114-117. doi: 10.4103/ ams.ams_233_18.

Baker, D. C. and Conley, J. (1979) 'Avoiding Facial Nerve Injuries in Rhytidectomy Anatomical Variations and Pitfalls', Plastic and Reconstructive Surgery, pp. 781-795. doi: 10.1097/00006534-197912000-00005.

Bourdon, N. et al. (2000) 'Facial Nerve: Vascular-Related Anatomy at the Stylomastoid Foramen', Annals of Otology, Rhinology \&t Laryngology, pp. 849-852. doi: 10.1177/000348940010900912.

Celik HH, Sargon M, Uslu S, Oztürk H, Sancak B. (1997) An anatomic variation of the stylomastoid foramen Paperpile. Available at: https://paperpile.com/app/p/ cdb 27795-b3d2-00c6-a631-5147560535d1 (Accessed: 30 June 2020).

Eapen, B. V., Baig, M. F. and Avinash, S. (2017) 'An Assessment of the Incidence of Prolonged Postoperative Bleeding After Dental Extraction Among Patients on Uninterrupted Low Dose Aspirin Therapy and to Evaluate the Need to Stop Such Medication Prior to Dental Extractions', Journal of maxillofacial and oral surgery, 16(1), pp. 48-52. doi: 10.1007/s12663-0160912-8.

Hessemer, V. (1994) '[Peribulbar anesthesia versus retrobulbar anesthesia with facial nerve block. Techniques, local anesthetics and additives, akinesia and sensory block, complications]', Klinische Monatsblatter fur Augenheilkunde, 204(2), pp. 75-89. doi: 10.1055/s2008-1035503.

Jain, M. and Nazar, N. (2018) 'Comparative Evaluation of the Efficacy of Intraligamentary and Supraperiosteal Injections in the Extraction of Maxillary Teeth: A Randomized Controlled Clinical Trial', The journal of contemporary dental practice, 19(9), pp. 1117-1121. doi: 10.5005/jp-journals-10024-2391.

J, P. C. et al. (2018) 'Prevalence and measurement of anterior loop of the mandibular canal using CBCT: A cross sectional study', Clinical implant dentistry and related research, 20(4), pp. 531-534. doi: 10.1111/ cid. 12609 .

Karaca, H. et al. (2019) 'Measurement of the depth of facial nerve at the level of stylomastoid foramen using MR imaging in Bell's palsy', Clinical Imaging, pp. 34-38. doi: 10.1016/j.clinimag.2019.06.008.

Kumagami, H., Nishida, H. and Dohi, K. (1976) 'Experimental labyrinthine lesions through stylomastoid foramen', ORL; journal for oto-rhino-laryngology and its related specialties, 38(6), pp. 334-343. doi: 10.1159/000275293.

Marimuthu, M. et al. (2018) 'Canonical Wnt pathway gene expression and their clinical correlation in oral squamous cell carcinoma', Indian journal of dental research: official publication of Indian Society for Dental Research, 29(3), pp. 291-297. doi: 10.4103/ijdr. IJDR_375_17.

Moreau S, Salame E, Delmas P, (2001) Arterial anatomy of the facial nerve at the stylo-mastoid foramen Paperpile. Available at: https://paperpile.com/app/p/ dde11ef4-5728-0461-897c- dc447b8cc586 (Accessed: 30 June 2020).

Nadbath, R. P. and Rehman, I. (1963) 'Facial Nerve Block*', American Journal of Ophthalmology, pp. 143-146. doi: 10.1016/0002-9394(63)91664-7.

Patil, S. B. et al. (2017) 'Comparison of Extended Nasolabial Flap Versus Buccal Fat Pad Graft in the Surgical Management of Oral Submucous Fibrosis: A Prospective Pilot Study', Journal of maxillofacial and oral surgery, 16(3), pp. 312-321. doi: 10.1007/s12663016-0975-6.

Ramadorai, A., Ravi, P. and Narayanan, V. (2019) 'Rhinocerebral Mucormycosis: A Prospective Analysis 
of an Effective Treatment Protocol', Annals of maxillofacial surgery, 9(1), pp. 192-196. doi: 10.4103/ ams.ams_231_18.

Schimek, F. and Fahle, M. (1995) 'Techniques of facial nerve block', British Journal of Ophthalmology, pp. 166-173. doi: 10.1136/bjo.79.2.166.

Senthil Kumar, M. S. et al. (2019) 'Inflammatory pseudotumour of the maxillary sinus: clinicopathological report', Oral Surgery, 12(3), pp. 255-259. doi: 10.1111/ ors. 12409.

Sweta, V. R., Abhinav, R. P. and Ramesh, A. (2019) 'Role of Virtual Reality in Pain Perception of Patients Following the Administration of Local Anesthesia', Annals of maxillofacial surgery, 9(1), pp. 110-113. doi: 10.4103/ams.ams_263_18.

Varshney, R. and Sharma, N. (2015) 'Morphometry of stylomastoid foramen and its clinical application in facial nerve block', Saudi Journal of Anaesthesia, p. 60. doi: 10.4103/1658-354x.146314.

Wahab, P. U. A. et al. (2018) 'Scalpel Versus Diathermy in Wound Healing After Mucosal Incisions: A SplitMouth Study', Journal of oral and maxillofacial surgery: official journal of the American Association of Oral and Maxillofacial Surgeons, 76(6), pp. 1160-1164. doi: 10.1016/j.joms.2017.12.020.

Wakasugi, B. (1972) 'Facial Nerve Block in the Treatment of Facial Spasm', Archives of Otolaryngology Head and Neck Surgery, pp. 356-359. doi: 10.1001/ archotol.1972.00770080550013.

Warner, L. O., Martino, J. D. and Davidson, P. J. (1995) 'Pulmonary edema after Nadbath and retrobulbar blocks: a possible explanation', Anesthesia and analgesia, p. 643. doi: 10.1097/00000539-199503000-00051. 